University of Texas Rio Grande Valley

ScholarWorks @ UTRGV

3-2021

\title{
Importation and Preliminary Evaluation of the Stem Boring Moth Buakea kaeuae as a Potential Biological Control Agent of Invasive Guineagrass, Megathyrsus maximus
}

\author{
Ann T. Vacek \\ The University of Texas Rio Grande Valley \\ John A. Goolsby \\ United States Department of Agriculture \\ Paul-Andre Calatayud \\ Bruno Le Ru \\ Boaz Musyoka
}

See next page for additional authors

Follow this and additional works at: https://scholarworks.utrgv.edu/bio_fac

Part of the Biology Commons

\section{Recommended Citation}

Ann T. Vacek, John A. Goolsby, Paul-Andre Calatayud, Bruno Le Ru, Boaz Musyoka, and Rupesh R. Kariyat "Importation and Preliminary Evaluation of the Stem Boring Moth Buakea kaeuae as a Potential Biological Control Agent of Invasive Guineagrass, Megathyrsus maximus," Southwestern Entomologist 46(1), 257-260, (25 March 2021). https://doi.org/10.3958/059.046.0125

This Article is brought to you for free and open access by the College of Sciences at ScholarWorks @ UTRGV. It has been accepted for inclusion in Biology Faculty Publications and Presentations by an authorized administrator of ScholarWorks@ UTRGV. For more information, please contact justin.white@utrgv.edu, william.flores01@utrgv.edu. 
Authors

Ann T. Vacek, John A. Goolsby, Paul-Andre Calatayud, Bruno Le Ru, Boaz Musyoka, and Rupesh R. Kariyat

This article is available at ScholarWorks @ UTRGV: https://scholarworks.utrgv.edu/bio_fac/129 


\section{Importation and Preliminary Evaluation of the Stem Boring Moth Buakea kaeuae1 as a Potential Biological Control Agent of Invasive Guineagrass, Megathyrsus maximus2}

Authors: Vacek, Ann T., Goolsby, John A., Calatayud, Paul-Andre, Le Ru, Bruno, Musyoka, Boaz, et al.

Source: Southwestern Entomologist, 46(1) : 257-260

Published By: Society of Southwestern Entomologists

URL: https://doi.org/10.3958/059.046.0125

BioOne Complete (complete.BioOne.org) is a full-text database of 200 subscribed and open-access titles in the biological, ecological, and environmental sciences published by nonprofit societies, associations, museums, institutions, and presses.

Your use of this PDF, the BioOne Complete website, and all posted and associated content indicates your acceptance of BioOne's Terms of Use, available at www.bioone.org/terms-of-use.

Usage of BioOne Complete content is strictly limited to personal, educational, and non - commercial use. Commercial inquiries or rights and permissions requests should be directed to the individual publisher as copyright holder. 


\title{
Importation and Preliminary Evaluation of the Stem Boring Moth Buakea kaeuae $^{1}$ as a Potential Biological Control Agent of Invasive Guineagrass, Megathyrsus maximus ${ }^{2}$
}

\author{
Ann T. Vacek ${ }^{3}$, John A. Goolsby4*, Paul-Andre Calatayud ${ }^{5}$, Bruno Le Ru ${ }^{5}$, \\ Boaz Musyoka ${ }^{5}$, and Rupesh R. Kariyat ${ }^{3}$
}

\begin{abstract}
Guineagrass, Megathyrsus maximus (Jacq.) B.K.Simon \& S.W.L.Jacobs, is an African grass that is invasive in Florida, Hawaii, southern Texas, and northeastern Mexico. Buakea kaeuae Moyal et al., a stem-boring African moth found only on M. maximus, was imported from Kenya and evaluated for its ability to feed and develop on Guineagrass naturalized in southern Texas. Neither larvae nor adults developed or reproduced on Texas Guineagrass.
\end{abstract}

Resumen. El zacate Guinea (Megathyrsus maximus (Jacq.) B.K.Simon \& S.W.L.Jacobs), originario de África, es considerado invasivo en Florida, Hawaii, sur de Texas, y noreste de México. Buakea kaeuae Moyal et al. es una palomilla especifica de M. maximus que ataca a los tallos de esta maleza. Esta palomilla fue importada de Kenia y ha sido evaluada por su habilidad para alimentarse y desarrollar su ciclo biológico solo en plantas de zacate guinea, naturalizadas en el sur de Texas. Ni las larvas ni los adultos de $B$. kaeuae, se desarrollan y reproducen en especies de zacate Guinea de Texas.

Guineagrass, Megathyrsus maximus (Jacq.) B.K.Simon \& S.W.L.Jacobs (formerly known as Panicum maximum Jacq. and Urochloa maxima (Jacq.) R. Webster), is an invasive grass in Florida (Overholt and Franck 2017), Hawaii (Daehler and Carino 1998), southern Texas (Lonard and Judd 2002), and northeastern Mexico (CONABIO 2020). This invasive African grass occurs in two distinct forms: giant and small with the latter invasive in South Texas, and the target of the biological control program (Mercadier et al. 2009, Rhodes et al. in litt.). The giant form has been found along the Rio Grande at Brownsville, TX (Soti et al. 2020). Megathyrsus maximus is native to much of Africa (CABI 2020). Giant Guineagrass is more common in lowland wet areas, along rivers and creeks. The small form grows in hot, dry upland habitats common in northern Kenya (very similar to South Texas). The small form may be a hybrid between Megathyrsus maximus and M. infestus (Panicum infestum) (Bon et al. 2011).

\footnotetext{
${ }^{1}$ Lepidoptera: Noctuidae

2Poales: Poaceae

${ }^{3}$ Department of Biology, and School of Earth, Environment and Marine Sciences, The University of Texas-Rio Grande Valley, 1201 W. University Avenue, Edinburg, TX 78539

${ }^{4}$ U.S. Department of Agriculture-Agricultural Research Service (USDA-ARS), Cattle Fever Tick Research Laboratory, 22675 N. Moorefield Rd., Bld. 6419, Edinburg, TX 78541

International Centre of Insect Physiology and Ecology (ICIPE), P.O. Box 30772-00100, Nairobi, Kenya

*Corresponding author: john.goolsby@usda.gov
} 
Small Guineagrass was introduced to South Texas as a forage grass and subsequently spread throughout the region. It out-competes other more valuable forage grasses and creates a large fuel load for wildfires that damage native brush species and rangeland ecology of South Texas. Guineagrass and other exotic grasses affect wildlife including northern bobwhite, Colinus virginianus L., and scaled quail, Callipepla squamata Vigors, because these grasses are not hosts of the native insect fauna. Juvenile quail feed mainly on insects and therefore lack sufficient food for development in exotic grass pastures. Also, exotic grasses tend to reduce the density and diversity of forbs whose seeds may be eaten by quail (Kuvlesky et al. 2002). In Mexico and along the border with Texas, Guineagrass interacts with the southern cattle fever tick, Rhipicephalus microplus Canestrini, by reducing populations of tick-feeding beetles and ants and by creating a cool, humid environment that promotes survival of ticks (Esteve-Gassent et al. 2014). Across South Texas, Guineagrass is very invasive in wildlife preserves, citrus (Citrus spp. L.) orchards, sugarcane (Saccharum officinarum L.) fields, urban landscapes, and along highway right-of-ways. Because this invasive grass is so widespread, mechanical and/or chemical controls are ineffective (Rhodes et al. in litt.). Biological control may be the best option of sustainable management of this widespread exotic weed.

Moyal et al. (2011) identified a new genus and species of specialist stemboring moths on M. maximus, Buakea kaeuae Moyal et al., which is specific to small Guineagrass of south-central Kenya. This specialist moth lays eggs on stems of Guineagrass, and the larvae bore into the crown of the grass. Because this insect is very damaging and already known to be specific to small Guineagrass, it was imported for evaluation as a potential biological control agent.

Three shipments of $B$. kaeuae were imported to the U.S. from Kenya in 2016. The insects were originally collected from small Guineagrass at Machakos, Kenya, and identified at the International Centre for Insect Physiology and Ecology, Nairobi, Kenya, by B. Le Ru. At the USDA Arthropod Quarantine Facility at Moore Airbase, Edinburg, TX, several methods were evaluated for rearing the Guineagrass moth. Newly hatched larvae were placed on cut stems or on two different artificial diets (European corn borer and southwestern corn borer diets - Frontier Scientific Services, DE). No larva fed on artificial diet. Larvae fed and stayed alive for more than 3 months using the cut stems of small Guineagrass. Larvae also fed on stems of giant Guineagrass but died within 6 weeks. Larvae were also placed on stems and leaf axils of live plants in both greenhouse and environmental growth chambers. No feeding was observed, and none of the 200 plus larvae survived on the Texas Guineagrass. We also received Guineagrass moth pupae from Kenya. Moths were kept in cages with small or giant Guineagrass for mating and observed daily. No eggs were observed from any adult moth.

In summary, all stages of the Guineagrass moth did not find Texas Guineagrass or the rearing system suitable. This probably indicated that Texas Guineagrass is genetically or phytochemically different from small Guineagrass at Machakos, Kenya. Stem-boring moths are generally difficult to rear, and this also might have contributed to the lack of rearing success.

This research was supported by the Lee and Ramona Bass Foundation. The article reports results of research only, and mention of a proprietary product does not constitute an endorsement or recommendation by the USDA for its use. USDA is an equal opportunity provider and employer. 


\section{References Cited}

Bon, M. C., J. Goolsby, G. Mercadier, T. Le Bourgeois, P. Poilecot, M. Jeanneau, and A. Kirk. 2011. What do chloroplast sequences tell us about the identity of Guinea grass, an invasive Poaceae in the southern United States?, p. 322. In Proceedings of the XIII International Symposium on Biological Control of Weeds.

CABI. 2020. Megathyrsus maximus [original text by J. Rojas-Sandoval and P. Acevedo-Rodriguez]. In Invasive Species Compendium. CAB International, Wallingford, UK. https://www.cabi.org/isc/datasheet/38666

CONABIO (La Comisión Nacional para el Conocimiento y Uso de la Biodiversidad). 2020. Panicum maximum Jacq. [original text by H. Vibrans]. http://www. conabio.gob.mx/malezasdemexico/poaceae/panicum-maximum/fichas/ficha. htm

Daehler, C. C., and D. A. Carino. 1998. Recent replacement of native pili grass (Heteropogon contortus) by invasive African grasses in the Hawaiian Islands. Pacific Science 52: 220-227.

Esteve-Gassent, M. D., A. A. Pérez de León, D. Romero-Salas, T. P. Feria-Arroyo, R. Patino, I. Castro-Arellano, G. Gordillo-Pérez, A. Auclair, J. Goolsby, R. I. Rodriguez-Vivas, and J. G. Estrada-Franco. 2014. Pathogenic landscape of transboundary zoonotic diseases in the Mexico-US border along the Rio Grande. Frontiers Public Health 2: 1-23.

Kuvlesky, W. P. Jr., T. E. Fulbright, and R. Engel-Wilson. 2002. The impact of invasive exotic grasses on quail in the southwestern United States. National Quail Symposium Proceedings 5: 118-128.

Lonard, R. I., and F. W. Judd. 2002. Riparian vegetation of the lower Rio Grande. Southwest. Nat. 47: 420-432.

Mercadier, G., J. A. Goolsby, W. A. Jones, and J. L. Tamesse. 2009. Results of preliminary survey in Cameroon, Central Africa, for potential natural enemies of Panicum maximum Jacq. (Poales: Poaceae), Guineagrass. Subtropical Plant Science 61: 31-36.

Moyal, P., B. Le Rü, D. Conlong, D. Cugala, B. Defabachew, T. Matama-Kauma, B. Pallangyo, and J. Van Den Berg. 2011. Buakea (Lepidoptera: Noctuidae), a new genus of African stem borers: morphological, ecological and molecular data. African Entomology 19: 23-35.

Overholt, W. A., and A. R. Franck. 2017. The invasive legacy of forage grass introductions into Florida. Natural Areas Journal 37: 254-265.

Soti, P., J. A. Goolsby, and A. E. Racelis. 2020. Agricultural and environmental weeds of South Texas and their management. Subtropical Agriculture and Environments 71: 1-11. 
Downloaded From: https://bioone.org/journals/Southwestern-Entomologist on 09 Apr 2021

Terms of Use: https://bioone.org/terms-of-use Access provided by The University of Texas Rio Grande Valley 